\title{
Subjectivities of Young People Demobilized from FARC in a Scenario of Peace Construction
}

\author{
Luz Marina Lara Salcedo \\ School of Education, Pontificia Universidad Javeriana, Bogotá, Colombia \\ Email: laral@javeriana.edu.co
}

How to cite this paper: Salcedo, L. M. L. (2017). Subjectivities of Young People Demobilized from FARC in a Scenario of Peace Construction. Open Journal of Political Science, 7, 82-100.

http://dx.doi.org/10.4236/ojps.2017.71007

Received: October 25, 2016

Accepted: December 27, 2016

Published: December 30, 2016

Copyright $\odot 2017$ by author and Scientific Research Publishing Inc. This work is licensed under the Creative Commons Attribution International License (CC BY 4.0).

http://creativecommons.org/licenses/by/4.0/ (c) (i)

Open Access

\begin{abstract}
This article presents the results of a research on the displacement of subjectivities of a group of demobilized young people formerly enlisted in the Colombian armed group FARC guerrillas (Fuerzas Armadas Revolucionarias de Colombia, Revolutionary Armed Forces of Colombia). Drawing on a social constructionist perspective (Gergen, 1996), this paper emphasizes a perspective of the subject formed inside the armed group-under new conditions, scenarios, personals traits and ways of living-, as well as the new subject that emerges after deciding to rejoin civilian life. The methodological design was oriented from the central premises of the social constructionist perspective. The methodological approach was the narrative inquiry with its three phases: production, analysis and interpretation. For analytical purposes, the model used was the narrative approach proposed by Coninck \& Godard (1998). The main results show that when the youngsters decide leaving the armed group, begins the transition to civilian life; it is a time of confrontation, doubts and fears that young people must face in their own way. The youngsters came from being immersed in an armed group that supported their identity. The transition implies losing a way of living, experiencing the uncertainty, but also with the hope of rebuilding their life projects. In this transit, youngsters feel unprotected and helpless; the values acquired of brotherhood and solidarity in the guerrilla life suddenly disappear and young people is confronted with a world of new social meanings and ways of being and doing. The results show the rupturing and continuities that rise in their subjectivities before and after joining the armed group, as well as the emerging and conflicting subjectivities in the process of disengagement. In addition, great fluctuations of emotional repertoires, as well as identity, ties, values and lifestyles go through a process of redefinition and reconfiguration to settle back into civilian society.
\end{abstract}

\section{Keywords}

Subjectivities, Demobilized Youngsters, Transition to Civilian Life, Reintegration 


\section{Introduction}

Colombia has suffered from internal armed conflict for half a century and has one of the five highest populations of internally displaced people. The people most affected by the conflict, both as perpetrators and as victims, are young people aged $12-24$. Between 11.000 - 14.000 are serving as combatants in armed groups-Human Rights Watch (2003); Watch List (2004); Coalition Stop the Use of Child Soldiers (2012); Coalition against the involvement of boys, girls and youth in the armed conflict in Colombia (2009). Other children and young people are working to plant, process and sell drugs. The struggle for territorial control of urban neighborhoods between insurgent fighters and paramilitary groups increased economic hardship and destroyed the social fabric of communities.

In this context, the main problem treated in this article was: which are the rupturing and continuities that rise in the subjectivity that the shift to civil life implies? The main objective of the study was to investigate the movements of the subjectivities of a group of former young combatants of FARC guerrillas (Fuerzas Armadas Revolucionarias de Colombia, Revolutionary Armed Forces of Colombia). Analyze the subjective processes that take place, the mechanisms that support the subject when he is no longer part of the armed group, as well as the logic derived from leaving the FARC and returning to civilian life.

This research emphasizes a socio-constructionist point of view. It aimed to gain a better comprehension and knowledge about the rupturing and continuities in the configuration of the subjectivities of the young demobilized by means of, an analysis of the narratives and it's signified. Here was important trying to find out which are the subjective logics that build the experience of joining an armed group and demobilizing from it, when the person has to start from scratch to construct a civil life.

In this transition, it is relevant to highlight the importance of subjectivity studies. Due to the fact that going back to the civilian life is an intimate decision, and as noted by Castro (1997, 2001), the subject feels unprotected and forsaken, finding himself suddenly in a new world with new social ideas that invade him and where the building of new social bonds is crucial.

The results of this research aim to contribute and compliment the investigations carried out by the ACR (Agencia Colombiana para la Reintegración, Colombian Agency for Reintegration). In addition, they might be of help in the formulation of peace education strategies that lead to disarmament processes, demobilization and reintegration back to civil life. In 2012 the National Government and representatives of the guerilla group FARC started a process of dialogue to end the armed conflict. These dialogues were formalized in a negotiating meeting on 18 October 2012 in Oslo-Norway. The peace negotiation continued in Havana, Cuba and on June 26 ${ }^{\text {th }}, 2016$ the bilateral Agreement and definitive cease-fire was approved putting down weapons, between the national government and the FARC. Finally, on August $28^{\text {th }}$ the Peace Agreement was ratified, with Cuba and Norway as guarantors and Bolivia, Venezuela and Chile as sponsor countries.

This agreement has generated optimism about the idea of working for peace in a transition scenario. In the armed post-conflict situation the Government with the par- 
ticipation of various groups of civil society has proposed programs and actions aimed to ensure sustainable peace and to attain social justice. In this process it is fundamental to provide a comprehensive care to victims, including demobilized youngsters, and creating the possibility of reconciliation and a real opportunity to live in peace.

\section{Epistemological References}

\subsection{Social Constructionism, a Methodological and Theoretical Perspective for Understanding Subjectivity}

Social constructionism is the theory that guided this research, particularly Kenneth Gergen's proposal $(1970,1996)$, which focuses on the historical and cultural character of knowledge, with social relationships and language as its main axis. Under this approach, the significations derive from the exchange we undertake in social microspheres, linked to patterns of cultural life; therefore, it is through them that we build the social reality (See: Estrada \& Díazgranados, 2007).

According to Social Constructionism, knowledge is not in people's minds, and words are not a reflection of the mind or a pre-existing nature: "the main source of the words we use about the world lies in the social relationship. From this angle, what we call knowledge is not the product of individual minds but of social exchange; It is not the fruit of individuality but of interdependence" (Ibañez, 1989: p. 169), posing a social epistemology where "the place of knowledge is no longer the individual's mind, but rather the patterns of social relationships" (Gergen, 1996: p. 167).

Therefore, exposing to socialization processes in an illegal armed group constitutes a set of experiences that subjects embed in their social practices. Bonds among people were made, ideas of a personal identity were formed (as well as a collective one), and a set of values was established, and these and other aspects constitute subjectivity.

The social interactions made, are a key to understand and read the movements of subjectivities.

From the theoretical premises of social constructionism that guided the research, it is relevant to highlight the knowledge as a social construct that demands recognition of culture, history, social context and relational context of stakeholders. Another fundamental premise for this research refers to the role of language in the construction of knowledge. Words acquire their meaning only in the context of social relations where we can build socially shared meanings and realities, questioning what we take for granted and opening new possibilities for action in terms of education, to influence the process of reintegration of the subjects.

For Gergen (1996), self-narratives refer to the explanation offered by a subject, about the relationship between vital life events over time. Therefore, in methodological terms the narratives configure our horizon of intelligibility, particularly using self-narratives as a conversational resource that enabled young people to establish coherent connections between experienced events and give meaning to their experiences, since selfnarratives function as cultural resources that serve to link the past with the present and future trajectories.

In this vein, it became necessary to look towards the social set of experiences in which the significations generated affectations in the subjectivities of young people. In 
addition, the ways to express them through their narratives, as this "talking about my experience" is a critical means through which we become intelligible in the social world, with significant meaning built through our relationships with others.

\subsection{Subjectivity, a Relational Process}

The context of social relations with others shaped subjectivities, with which social life is built through the cracks, pains and possibilities that opens the conflict between humans, i.e. subjectivity is crossed by the personal and collective significance of experiences, as well as the configuration of meanings that guide the actions.

For Torres (2000: p. 8), subjectivity "refers to a set of instances and processes of production of meaning through which individuals and social groups construct and act upon reality, while they are constituted as such. It involves a set of norms, values, beliefs, languages and ways of apprehending the world, conscious and unconscious, cognitive, emotional, volitional and erotic, from which subjects make their existential experience and senses of life".

According to Arfuch $(2002,2005)$, subjectivity is related to language and social interaction, i.e. with those relational, symbolic and political dimensions of the subject in interaction with another, and implies in turn that desires and positions can be contradictory. Arfuch states that it is in language and through language, that man becomes subject, and subjectivity comes into play through the power of expression to consider himself as such, i.e. as a subject who emerges through language; therefore, the symbolic/ narrative dimension is constitutive of subjectivity, as more than a simple evolution of stories. It is "a necessity of subjectivity and identification... that allows articulating... an image of self-recognition" (Arfuch, 2002: p. 65).

Thus, subjectivity refers to a process of construction of meaning, a process of individual and collective character in which subjectivity and time are set in the language, because when telling a story, the configuration of subjectivity takes place. Not only those processes related to a personal biography, but also those related to life contextualized in cultures that transfigure the subject in a subject that needs to be understood, interpreted and constructed. Therefore, it is in permanent construction and it is susceptible to being transformed, which points out the unfinished character.

Hence, subjectivity emerges in relation to others, not in a vacuum. It depends on the structures of relationships, as well as cultural processes in which we operate and the language we use to help us understand. When narrating our lives, we are not only narrating telling our lives to others (and to ourselves), since as noted by Gergen (1996), narratives "are not the product of life itself, but constructions of life."

Therefore, we can infer four transverse dimensions of subjectivity that are useful from the theoretical and methodological perspective of this study: the power of language in the social construction; the relational framework of experiences with others as a backdrop; the expression of stories and narratives through which subjectivity emerges, and the cultural context in which subjectivity is constructed and re-created.

\subsection{Methodological Approach}

The methodological design was oriented from the central premises of the social con- 
structionist perspective, hence the narrative research approach with its methodological assumptions.

Using this narrative approach, I collected narratives of young people through semistructured interviews and focus groups to examine some experiences the lives of the former combatants. The methodological process developed addressed three phases: production of narratives, narrative analysis and interpretation of narratives. For analytical purposes, I use the model of the narratives proposed by De Coninck \& Godard (1998). The archaeological, who sought to identify the nodal points where life stories took a turn; and the trajectories, which allowed us to establish the routes and transitions experienced by subjects, indicating the processes that led to the changes. The type of analysis was the holistic narrative and for the focus groups, the conversation analysis model.

Population: In this, research different actors intervened to the production phase of narratives, but the results presented are only from the ex-combatants: ten narratives by young demobilized who belong to Program of the Services Center of the ACR (Colombian Agency for Reintegration) in Ibagué, through interviews and the focus groups technique.

\section{Results}

\subsection{Subjectivities that Emerge, Subjectivities in Conflict before and after Joining the Armed Group}

\subsubsection{The Entry of Young People into the Armed Group: The Subjectivities of Hope}

The investigation established that the factors associated with young people joining armed groups were related to the context of poverty, the desire to financially help their families were, a lack of opportunities to become "someone", and living in areas of violence. These factors, along with the fact that young people were looking for recognition, status, support and a sense of identity in a critical stage of their development, combine in favor of armed groups. How? Setting the stage where young people see in them a hope, a chance to step in and play the role or roles that allow them to achieve their dreams. That hope is the reason why they end up joining.

As we can see, many of the factors associated with joining armed groups like identity and recognition, human needs theories consider them as basic human needs. But, at the same time there are other factors, such as security, money, food, welfare, fostering, that operate to warranty a future. We can say that these factors make young people join the group because they perceive it as the only way out, hoping to find "something" to improve their situation. We can also say that in those searches a "subjectivity of hope" emerges, a horizon of life with new meanings, in which they will need to prove to themselves and to others that they are able to adapt to the logic of war and become warriors.

\subsubsection{Life in the Armed Group: Transit from Subjectivities of Hope to Subjectivities of Obedience}

The findings indicate that upon entering the armed group, the subjects faced a very strong system of discipline. The scheme included a system of routines, rules, standards, norms and behaviors that led to a kind of uniformity characterized by loss of autonomy 
and that ended up transforming into a bond that we could call "domestication", here the lives of young people was limited to obedience, because they are part of a military body as long as they obey:

"I had to obey and comply; practically it was the same every day. walking, eating, if they send you to some place, you go because they are telling you to go, ¿right? because they tell you, what to do". (Former combatant of FARC. Female. Interview \# 6).

"At first it was alright, but then it was harder because it started to annoy me, I had to obey everything they said, even if I did not want to". (Former combatant of FARC. Man. Interview \#3).

"What they say there is '!' Rules are obeyed or the militia is over!" (Former combatant of FARC. Man. Interview \#7).

We can deduce that the dynamics within the armed group make it what Goffman (1961) referred to as total institutions. The author believes that total institution absorbs all of the time and the interest of its members, and provides them in a way his own world. Your totalizing tendency manifests barriers to social interaction with the outside and the flight of individuals

On the other hand, the findings show that the strategy of control and domination used by these groups towards the young members is fear. According with Jiménez (2011), it is a socially constructed fear that penetrates through the individual and collective imaginary until it is a part of their lives. Even from the first day, they are intimidated not to escape, threatening to kill them or their families. Thus, the armed group sets a benchmark of collective fear:

"I remember when I got in, they said' you joined us alive, the only way to leave is as a dead man' Everyone knows there is no way out, when you join the group you are involving your family. You are told that if you leave, your family will pay the price". (Former combatant of FARC. Female. Interview \#2).

One of the key processes in total institutions is the question of self-mutilation; Atehortúa (2005: pp. 95-96), regard that "the individual comes to the establishment with a conception of himself that certain stable social arrangements of their usual environment made possible says. However, just entering such institutions, he sheds the support they gave him their usual environment for him and begin a series of depressions, degradation, humiliation and desecration". Thus, the mechanisms of repression used in the group become a matter of production of fear, the methods ranging from physical and corporal punishment before the eyes of all, to war councils deciding who lives or dies. This depends on the soldier's good behavior, which is associated with obedience and discipline, and if the person is a good warrior:

"The thing is that what really counts is the behavior you have had, your discipline and if you have been a good warrior. In those war councils, the commander can order, 'Kill him', but if there are 25 people and 20 do not agree with the decision, they do not kill him. It is harder when there is a tie because they revoke it". (Former combatant of FARC. Female. Interview \#6). 
Moreover, in cases in which there is an attempted escape and it is decided to spare the lives of young people, commanders assign exemplary and "deserved" punishments because the fault is considered treason. These penalties range from tying them for a period, usually two months, to writing whole pages about the rules, or putting them to forced labor:

"My punishment was to dig a $400 \mathrm{~m}$ trench, 20 deep. He (her partner) had to do 500 meters and me, 400. I also had to dig 60 holes a meter wide and one meter deep to dump the trash in, all that in a month. Another month I was also making latrines, holes in the ground where one defecates. In addition to the punishment, 100 hours were bearing the largest empty pot and my husband 100 hours carrying the largest pot that was in the unit. You also have to write pages about the crimes committed, the rules and discipline”. (Former combatant of FARC. Female. Interview \#6).

It is noteworthy that the young woman states that she "deserves" such punishment, justifying, among others, the dependencies with the group and forms of violence with which they are treated. This reflects in turn, naturalization of relations of domination and installation of the subject in these relationships and these logics, thus assuming the daily life within the group. Naturally, the situation is similar for those who were members since childhood and practically raised in the armed group. Here, there is a prevailing regime of obedience, but also a process of subjected to a disciplinary regime, where "winning the affection" is not only synonymous with obedience, to fulfill the tasks, but also to gain protection and perks with shifts, food or shelter.

In this regard, Butler (1997: p. 13) from a psychoanalytic perspective tells us that the power not only produces the borders of the subject, also permeates his interiority. Has a double valence, subordination and production: 'the power that initially appears as an external pressed on the subject, pressing the subject to subordination, and assumes a psychic form constitutes the identity of the subject'.

\subsubsection{Life in the Armed Group: Conflicting Subjectivities}

As we have seen, young people end up in a regime of strong discipline built through fear. By delegating their support to the armed group, they leave the control and direction of their lives in its hands. According with Jiménez (2006, 2011), this leads on the one hand, to authoritarianism within the group as a way of exercising power and ruling their lives, and on the other, that the lives of young people are reduce to relations of dependence and submission. Therefore, the question arises what kind of subjectivities emerge under these circumstances. Most interviews show the disappointment and sense of powerlessness that these young people were feeling, finding themselves as in a "dead end" road, shortly after joining the group. For many, the answer is resignation and getting used to the regime. We are thus speaking about domesticated subjectivities.

"And then, when one is there, what you have on your mind is that you must be there, you know? You have to be there. You have to pretend, but deep down in your heart you don't feel it. Since they took me away, I knew it was up to me to belong, I had to, but that was not voluntary". (Former combatant of FARC. Female. Interview \#6). 
In other words, this means a process of being subjected to a disciplinary regime, and a way to adapt to the regime. In this context is formed what we call a subjectivity of resignation, which in the case of these two guerrilla members, was accompanied by emotional repertoires of anger and bitterness due to the experiences that they lived at a very young age.

The results also show another manifestation of subjectivity we have called, repentant subjectivities. These are those related to recognizing errors in decision-making, and therefore, having no other option but to accept the consequences of their decisions:

"You live just because you are alive, try to picture this: I entered the group when I was only 15, what do you think of life at that age? Nothing, silly stuff. And when you wake up and see what you did, you realize the mess you got yourself into, there is nothing left to do, and you are screwed". (Former combatant of FARC. Man. Interview \#3).

"In there you live for the group. All you think of there is the group this, the group that. Aroutine life. Every day the same. I thought, 'I screwed it when I decided to come here”.' (Former combatant of FARC. Man. Interview \#7).

In the above fragment the metaphorical expression "when you wake up", is understood as an allusion to the reality that was revealed when experiencing certain conditions within the group and not having realized it in the moment of joining the group because of the young age they had. We should also mention that in adolescence there is a taste for weapons, uniforms, and the need for recognition, as demonstrated by the results of this study. These young people do not have a realistic idea of what is behind all of that. Likewise, the term "being screwed" denotes not only an unworthy place to live, but also the emergence of a subject of rights because of the exhaustion of the reasons for being a member of the armed group and the changes that have taken place in their subjectivities.

As we emphasized at the beginning of this article, young people come to the group with high hopes and are very optimistic about a new life and future. However, this peaceful coexistence and very little responsibilities and requirements end soon and suddenly that "honeymoon" is over. The regulations, the military regime, the living conditions in the jungle and the disciplining starts generating affectations in the subject's life, deriving subjectification processes that make the subjectivities of young people enter in conflict:

"When you enter the group, the first eight days are really good. Then you start to think about what you did, that you made a mistake, because conditions get tougher. So you start to think twice how do I get out, who do I talk to, what do I do?".

(Former combatant of FARC. Man. Interview \# 7).

On the other hand, the lives of young people become blurred as the dynamics of the armed group and the military take the overhand. For this reason, their life begins to revolve around the group and they must give up their own life. This transformation requires them to learn to see life through the eyes of the group and it demands of them. It is as if their subjectivities were suspended in time, waiting for an opportunity to emerge again: 
"It was the same if it was Monday, Tuesday, Wednesday, Friday, Saturday or Sunday. When you are there, time just passes by. You do not even know if it is Saturday or Sunday. I don't know, it was like things happen and you' re just there... there's just no project or nowhere to go to." (Former combatant of FARC. Female. Interview \# 1).

In these circumstances, young people can only assume that lifestyle attached to the group and perform the duties and responsibilities they were assigned. However, it should be noted that adaptation is not easy for all young people, it implies an abrupt change in lifestyle and routines, waking up very early, turns to be met in the guard, long days walking and with heavy luggage, constant rain and in many cases, they must stay wet without the right to take a break. On the other hand, it also involves changes in the quality of food, in the eating and sleeping hours, the loss of privacy, and others. All this, combined with the emotional load generated by the system of discipline with punishment, obedience, and for many, the absence of their parents, particularly the mother figure:

"We had to train, carry water, wash clothes, do guard. Adaptation for me was hard because we had to walk in the rain, being wet, there where snakes, we had to charge up to four pounds of luggage, food, weapons, ammunition, sleep outdoors, and the harassment". (Former combatant of FARC. Female. Interview \# 9).

On the other hand, when assuming the roles of obedient fighters, there was a positive side also, for example the development of physical endurance, strength, courage and bravery, aspects that gave them recognition and visibility within the group. We must also mention that facing danger and the imminence of death on many occasions, a subjectivity that revealed their finitude came up, recognizing the vulnerability of their lives, that their days could be numbered, that death lurked at any time and that the experience they were living, could end their lives. Paradoxically we can say that from day one, the horizon of their life is death:

"When you' re there, your life is just hanging on a thread. If you get hurt, no one's going to take care of you. Depending on the wound you have they decided whether to finish you or to help you. You know that if you do not aren't killed in combat, you are going to die out there anyway. Because you don't ever get out. Sometimes they tell young people to join, that they are free to leave whenever they want to but it is a lie. You leave when you're dead or because you escaped." (Former combatant of FARC. Female. Interview \#2).

"Well, practically in there you' re just wasting your life. You can die any moment. You just think whether to stay or not. You don't think much, you don't look to the future, and you just walk. Watch for mines, maybe a little combat up there, you got killed and you' re life's over. That's the thought you have in mind all the time, that's the thought you live with." (Former combatant of FARC. Man. Interview \# $8)$.

However, in the context of these subjectivities, let us consider how these young people saw life when they were in the group. As was to be expected, all agreed that there 
was no glimpse of a future, nothing for them individually, as they were subjected to the control of the group. There are even those who say that sometimes they only "saw life" and others who "did not see their life at all." This explains the emergence of a subjectivity that we dare to call subjectivities of emptiness (or boredom?), as they are configured without a horizon of expectations and opportunities, where every day was the same and life is merely obeying and fulfilling orders:

"I used to see life as a cloud, too bad! You do not see any chance coming. Like a white paper. Like a constant wait. Wait to be shot in the head. Life while being there is nothing. In addition, after being there, you cannot do anything about it! There are no normal days, just mountains. While here in the city there are crowds on Mondays, and on Sundays there's very few people outside". (former combatant of FARC. Man. Interview \# 3).

"Sometimes I would see life. However, really you do not think of nothing, you do not think shit. Just do what you are told to do and being there. You do not think about anything because you do not have to think about no one else, you don' have to pay your bills, none of that. You just think about complying orders." (Former combatant of FARC. Female. Interview \# 4).

\subsection{Emerging and Conflicting Subjectivities in the Process of Disengagement}

As we have seen, relationships in the group move from trust to fear due to the discipline the subjects are put under. In this scenario, fear is a powerful strategy to control and dominate their lives in different relationship aspects; however, facing the ambivalence of their feelings, it also creates a need for reflection and finding new horizons and opportunities for their lives. A time of revelation commences, through processes of subjectification, creating a conflict between subjectivities of obedience, boredom and resignation, which demonstrate the finitude of existence. It is like being in a rut, hesitating while glimpsing out. In this process that begins to forge, certain motives arise, certain motivations in the subject that are claiming for them a decent life. These subjective moments clear the way for an emerging subject who wants a different life for himself and begins to decide that deserves to live in dignity.

These aspects will be addressed in the following section through two analyzers. In the first place, we point out the factors of disengagement found as the most relevant; and secondly, we will give a look at the transit that the young people must travel and how they live this experience.

\subsection{Disengagement Factors}

Now, we want to know what prompted the departure of young people from the armed group, what it was that made their links, loyalties and motivations regarding life in the insurgency weaker. We will look into these key elements in the paths of young people, embedded differently in each individual, to decide on to disengage from the group. As we shall see, some factors began to lead the way towards the exit from the group in search of a new destination, as the opportunity they saw to build a life with arms, a life in which they hoped to have it all, ultimately showed them that they had built nothing. 


\subsubsection{When the Group Disappoints Young People}

Although the group was to the young people a host community that offered some security, protection, the situation of confrontation in war affected these subjectivities, and the relationship of trust built with the group, started deteriorating. Thus, the chores of life in war influenced to change those relations and they saw them differently. Several of the young people interviewed shared this point of view:

"That was here in Tolima, known to be a' red zone'. It was two in the morning and we had stopped to make breakfast. That time I was in blight, which is when you eat, and it was my turn. We heard a plane, there was a boy who was with me that had been in that situation many times. He said that if the thing kept flying in circles for more than 6 times, we were going to get bombed. Moreover, he was right, 4 times, 5 times and we decided to run at the sixth time. As soon as we running the bombs started to fall and the combat began. Holy God! People have little or no time to shoot, the only things you can do are to run and keep running. You cannot do anything else because all they do is throw and keep throwing bombs at you. Holy God! That is a terrible thing to live. I had to get out."

"We ran a lot that day, and they kept shooting, and then the army was hunting us down in the jungle. Many people died. Many new girls who had just gotten in, they told the commander to help themi and you know what he answer. He told them to do what they could, and they were left behind to die. There were many pretty girls, about 14 years old. In addition, that is where I thought Holy God! I prayed and asked him to give me a chance to get away, a chance to be free again. We kept on running for two days."(Former combatant of FARC. Female. Interview \# 2).

\subsubsection{When the Female Condition Is Assaulted: Between Indignation and Injustice}

In a context of armed conflict in the mountains or in the forest, pregnancy and motherhood are problematic for the safety of the group, which is why the young women have to use contraceptives and birth control methods. If this rule is broken, they receive sanctions and usually are forced to abort. This experience related to womanhood, was one of the most crucial factors that triggered the decision-making in young women, and made these decisions irreversible. We will now have a look at a revealing experience that marked the end, of the life of a young girl within the armed group.

Is the case of a young woman, who never contemplated the possibility of withdrawing from the group, she considered it her family since she joined when she was eight years old. The fact that she was anesthetized to interrupt an 8-monthpregnancy was the fulminant trigger for her to undergo subjectification processes that led to her departure:

"I was around twenty years old when I got pregnant. I hid my pregnancy until I could no more. They started to follow me all the time, they drew near me, and they would not leave me alone, as if I were a dog. I would kick them and bite them. Late at night, they would come offering me pills. No thank you, no pills for me. I would not take pills or anything and since they could not do anything, they anesthetized me. My daughter was born alive and fully developed because she was already eight months old when she was born. She died there. That was the biggest factor that 
made me decide to leave. I always thought I would die there, because I liked it there. ¿I used to say why I should go back. What for? The more days you spent there, the more you fall in love with that kind of life." (Former combatant of FARC. Female. Interview \#5).

According to the findings, the trigger for emotional disengagement from the group is being pressed to abort a pregnancy, the action of abortion or the death of an infant. These are experiences related to what Goffman (1961) calls "the mutilation of the self," and which begin to generate moral feelings like anger, indignation, pain and resentment.

It should also be note that there are some cases in which the group agrees that the pregnancy should be allowed to continue, but with the condition that the mothers leave their child with their families, a situation that young mothers are not willing to take. Therefore, their subjectivities enter into conflict and they prefer to escape. They choose to reject the group instead of giving up their motherhood.

However, it should be clear that the practice of abortion cannot be generalized, not in all cases, the guerrilla group interrupted pregnancies, in particular, when the girl has a high rank within the group or she is the companion of a commander.

On the other hand, we agree with the approach of Londoño \& Nieto (2007) when they say that while the practice of birth control and abortion can be interpreted as forms of control of the female body, it is also explicable in scenarios where men and women have an active sex life, but with little chance to complete pregnancies and raise children in adequate conditions for both mothers and their children. Likewise, we agree with the authors when they state that the use of contraceptive methods in illegal armed organizations, aims to build a free and responsible sexuality, but "the instrumentalization of the female body with a functional purpose for war" (Londoño \& Nieto, 2007: p. 241).

\subsubsection{When the Issue Is Living a Decent Life}

Moral feelings of anger and indignation felt by young people when they realize they are not living a decent life are the beginning of the struggle for the recovery of their dignity. In this conquest for dignity, we met several young people, as subjects with rights, who initiated a process of reflection on their own existence and struggle through processes of subjectification, not only externally but also internally. Jimenez (2006: p. 46) points out that when personal life is assumed without asking for permission, emerges the human rights subject, and guided by a pedagogy of disobedience, advances on his emancipation from all chains with the possibility of assuming, facing and addressing his personal and community life.

At this point movements of their subjectivities commence, from a subjectivity of obedience and submission, to a rebellious subjectivity and newfound hope to find in civil society a place to live a life in dignity and justice:

"When I was almost 17 years old, I began to see that it wasn't normal, that it wasn't a good life for a human being. I saw it because you get wet all the time. One sees that it is not a normal life, which is the life for pigs! You begin to think that you are missing things, sometimes you do not get your cleaning implements, and 
that there is no toothpaste and the soap to bathe. When you are young you do not see none of that, you just do not pay attention to it. Then you start to realize that there is no use to that. Also having a partner, having children, all these things make you think differently, wanting to start a home. That is when you change the way you think... The rain started to bother me, to affect what they call the morale. When you have to stand guard, and the water falls, and you are wrapped in plastic... everything started to annoy me!" (Former combatant of FARC. Male. Interview \#3)

This story shows a man with experiences related to his own body, revealing experiences about the dignity of humans and, to say the least, he decides to seek new horizons of meaning for his life. It also arises in him the need to create new links, in this case with a partner to start a home. Beyond this, we can say that we find a subject that does not reduce his life experience to his personal life, but that links it to another-a partner-and a few others-their children-that will replace him and what will be his continuation.

\subsection{Subjectivity in the Beginning of the Transition to Civilian life}

With the departure from the armed group, a subjective movement starts in the person, which launches a new hope of their lives again. The way the escape takes place is relevant, because in the case of individual demobilization there is no roundtable or previous agreements. To top that, these young combatants are considered by the group as deserters and become military targets, as they are seen as traitors to the cause. Practically they start this process from the underground and in their new life; they feel helpless, because they are not prepared to lead a life of their own. Additionally, they are not able to meet the challenges of returning to civilian life in a usually urban context, and many questions begin to arise, questions that they cannot answer yet: Who am I now? What do I do? What will my life be like now? Did I choose the right path? Will they be chasing me and until when?

Furthermore, escaping involves the processing of moral sentiments such as treason and disloyalty, which makes the picture even more complex. As they set up their new subjective horizon, they will live in a time of uncertainty, insecurity and fears, passing through a world of change and transition, with strange places and strange people. It is a time of return to the subject, in an unknown place, thinking again about the self to decipher one's own identity and new ideas about who to be and how to act. It is a time of uncertainty, where the subject is confronted to feelings of being adrift and calls the subject to confrontation:

"When you leave you feel empty, one wonders where do I go, what shall I do, what will become of me? Because you' re in the city where you don't know anyone, it is very tough, so that is then what you feel: fear and despair." (Former combatant of FARC. Female. Interview \#2).

"The truth is that you feel very distressed and sad thinking about what you are going to do next..." (Former combatant of FARC. Female. Interview, \#1).

"I had both, hope and fear..." (Former combatant of FARC. Male. Interview \#7). 
Undoubtedly, these are times that form a new subjective horizon, where identity, ties, values and lifestyles necessarily go through a process of redefinition and reconfiguration, as the subject needs to "reinvent" and gradually to earn a place, to settle back into civilian society. As we see, this brings along fear, but also hopes to be accepted and recognized, and for this, each person requires a subjective time for processing the situation.

Moreover, it is not surprising that at the beginning of this transition, most young people long for the first reunion with their families; however, they are not aware that they will have to go through several destinations, where they will probably experience processes of connections and disconnections, until they finally reach a spatial stability. This is the case of a young man who had to move from the battalion to Chaparral, then to a correctional facility in Ibagué, then to Bogotá and finally to Ibagué again:

"I went downhill to the town, to the farm where my parents lived. There I was surrounded by the army and they started to ask me questions, and I started to lie to them. They told me that I had escaped and that 'those people' were looking for me. And they started to tell me things, they told me to turn myself in, that if I returned I was screwed because they would kill me in the mountains. Then I was filled with anger, you know? And they told me some stuff until finally I cried. Tears streamed down my face and they told me 'you have to start a new life' So they took me to the battalion, and the next day I was brought to Chaparral." "I stayed in Chaparral for eight days, and then I came to a correctional facility in Ibagué. I stayed there for a month, then I went to Bogotá and stayed in some foster homes during eight months and then I was taken back to Ibagué to the 'Hogar de la Joven' [Home for Young Women]. After two months I said no more, let me be free and I asked them to let me be with my family. But those were changes I was not expecting, those changes were very difficult. That was in 2004, since I left in 2003 until 2004 I spent all that time, and I was very bored because I was so far from my family, and all I wanted to do was to see them again and to be with them". (Former combatant of FARC. Female. Interview \#2).

It should be note that during this transit young people experience feelings of confusion, abandonment and loneliness, while the detachment from the group is now becoming definitive. In this context, the hosts that receive these young people at that first moment are essential to provide them with an atmosphere of safety and tranquility, because they are uninformed and afraid that they could be beaten or taken to jail:

"When I demobilized, the people who picked me up treated me well, they explained everything to me, and then the feeling that I was already coming out of that green patch started to come. Because that green patch is everywhere, a green patch all over the country. I felt hopeful. Anyway, my brother had already demobilized and nothing had happened to him, he wasn't taken to jail. Because that's the biggest fear you have. Because they use a lot of psychology, if you leave, you will go to jail, you will get killed. They scare you a lot and that's always in your mind when you decide to leave". (Former combatant of FARC. Male. Interview \# 7).

Nevertheless, to choose a new path, as we see, is also to confront new fears. First, a natural fear of the unknown arises as strangers surround young people. They do not 
know where they will get, with who will they live, and how secure they are. Second, following the loss of their identity references and not knowing who they are, their identities are in crisis. Third, they fear to lose the power to decide for himself and have others again taking control of their lives:

"It really scared me, that feeling of not being yourself, because they take you to those foster homes, and you don't know where it is that they' re taking you". (Former combatant of FARC. Female. Interview \#2).

"Even cars scare you..." (Former combatant of FARC. Male. Interview \# 7).

"I was afraid of people..." (Former combatant of FARC. Female. Interview \#6).

Additionally, they are required to begin to take care of themselves in order to meet their basic needs and restore the maintenance of themselves that they had delegated to the guerrilla group. In addition to these concerns are added those of his safety, fearing to be recognized by a band mate, be betrayed or end up dead. Undoubtedly, the experiences of these young people are experiences that we dare to say, leave them aged even if they are still young.

We cannot conclude this section without mentioning that many of the young demobilized, after being presented to the appropriate authority, are used by the army to obtain information or plan operations, although this is prohibited by law:

"And that's when they offered me money, they showed me 20 million pesos on a table. Those would be mine if I went and helped with the killing of El Pollo Libardo, that would be mine if I turned into a snitch, that would be mine if I went back and dug up a radio and some stuff that I had left hidden. I told them I wouldn't, because I wanted to protect my family and I didn't want to tell information about the people with whom I had shared so many things and time. And I didn't go." (Former combatant of FARC. Female. Interview \#5)

On the other hand, young people entering civilian life entails several changes, leaving the military, the guns, the camouflage, the boots, out of hiding and join legality. All of this implies the construction a new political subject, with new ways of acting; it also involves immersion in social life as citizens and not as guerrilla fighters. All these changes compromise their subjectivities and demand the construction of new social links and the recreation of values that facilitate the return to civilian life and prepare youngsters to take care of themselves, to make their own decisions and take on new challenges in civil society.

The carefully selected testimonies have enabled us to understand the transition these young people must go through. We have found some subjects whom in their patterns of social, political and cultural relations have ranged from disappointment in the army life and hope into civilian life. They are subjects living dichotomies: from living for others, to live for themselves; from a community life in an armed group to another life in the unarmed individuality; from a life in illegality to another life within the margins of the law, etc. The list of these dichotomies could be endless.

\section{Final Considerations}

This study identified some nodal elements in the transformation of the subjectivity, 
reflected in rupturing-subjective movements that produce a break and mark a before and an after-; and continuities, as some aspects are kept in the path to civilian life that will manifest in the future as a continuation of their past life.

In this sense, Castro (2001) points out that the renunciation of the youngsters' name itself implies a break of the subject that mark them in their subjective history, although the main break of youngsters is life changing. Similarly, to leave the "armed force" implies for young people to break links and they must cope with the loss of identity and horizon. Regarding to the continuity, discipline, respect and loyalty they continue as values that guide their actions, accompanied by an attitude of distrust, because it meant a survival mechanism in the war, which seems to become more pronounced in civilian life, along with new fears, because young people are in new contexts.

We need to consider the young subject beyond biological boundaries such as age, and think in their ways of being young. We must try to recognize their characteristics and specificities as juvenile subject, in order to achieve an understanding of their complexity and from there, to interrogate reality.

The concept of youth in itself demands a trans-disciplinary perspective and the assumption of its problematical and complex essence, to define the specifics of the youth and thus gaining a greater understanding of their way of life. According with Alvarado (2009: p. 100): "thinking about youth is venturing into the reconstruction of the worlds of life, with different temporal and spatial awareness than those encountered in the adult world".

On the other hand, it is necessary to note that conflict is inherent to societies and that it constitutes a source of emerging identity statements, where the juvenile is understood to be vital as it helps social phenomena to become evident. Manifestations of identity in the case of young people who enrolled in groups outside the law, who for different reasons-socio-economic exclusion, poor living conditions, family violence, attraction and liking for weapons and the uniform, the need for recognition, among others. In that vital search, they ended up migrating to new territories, in terms of Reguillo (2000), generating identity affiliations, where they assumed discourses, practices and aesthetic warrior that later, in their condition of demobilized, they will not be able to leave easily.

The findings of this study are consistent with those of Brett \& McCallin (1998) entitled "Children: the invisible soldiers", and which shows some key factors for adolescent participation in conflicts, such as belonging to the most disadvantaged and poor sections of society, to the very areas of conflict and coming from broken families. In addition, that "voluntariness" that the young manifest when enlisting, is linked to situations that are out of their hands and pushes them to make the decision to join. With regard to education, we agree with what is reported by the above authors, in that for children and young people access to education is a determining employability factor, which will enable them to support their families and give meaning to their lives and therefore, this is one of the factors that can make a difference.

Following up on the factors of joining an illegal armed group, there were several points our study has in common with the one carried out by Brett \& Specht (2005), "Young soldiers: Why they choose to fight". The causes of joining were studied for 
children and young people from nine countries: Afghanistan, Colombia, Congo, Brazzaville, Democratic Republic of Congo, Pakistan, Sierra Leone, Sri Lanka, Northern Ireland and the UK.

With regard to the causes found that question the voluntariness, and which also appear in our study, we find poverty, the fact of living in conflict zones, the origin of dysfunctional families, and dissolved or no education, circumstances which together with age-appropriate characteristics, form a powerful trigger for deciding to be recruited. However, although the study notes family and friends as the most significant factors in linking young people to the armed groups, in our research we found the most mentioned factor to be the identity of young people associated with indicators such as the attraction for weapons and a taste for the uniform. As a second factor emerged the need for social recognition of their abilities and capabilities in their original contexts.

With regard to factors such as poverty, war, family and education, we also have meeting points in gender topics with the Voices of young veterans investigation conducted by Keairns (2004) in four countries (Sri Lanka, Angola, Colombia and the Philippines) with young women under eighteen years of age. For Colombia, we found the same risk factors that challenge the "voluntary joining": being poor and marginalized, living in a combat zone and separated from their families. Additional risks include education (dropping out); not being able to influence the decisions of life, and, being marginalized from the new family structures and finally, not being protected by the family.

Now, with respect to the beginning of the demobilization of the young, we agree with Lara \& Delgado (2010: p. 36) when they say that "those same logics that the subject constructed to settle in the war, when they don't find a support, when they no longer satisfy and meet the expectations, will begin to point the way back to the exit". This situation generates subjective movements in order to undo the life within the armed group and prepare for the unknown awaiting you.

These subjective movements themselves are an opening to confrontation, as Castro (2001) points out; each person will resolve it on their own and in a subjective time. The voices of young people show that this transition is a period of rapid changes, uncertainty, confusion and loneliness, accompanied by feelings of fear, anger and anxiety, in addition to the moral feelings of disloyalty and treason against the group where they once found a welcome and a support in their lives.

The processes of joining and leaving the illegal armed groups set forth a great mobilization of emotional repertoires, which involved intense emotional transformation from the emotional to the rational and from the collective to the individual, accompanied by emotions focused on the future, which encourages them to make the decision to escape. In this regard, it should be borne in mind, that 'emotions are forged in social interaction, are structured in terms of status and power and are expressed based on cultural understandings (Bolívar, 2006: XXIX). Hence the importance of recognizing the discursive life of the emotions of young people and in particular of language in understanding what they feel, what they should feel or what they may feel in these processes.

Also in the process of returning to civilian life of young people, it is relevant to point 
out what Bolívar says regarding emotions when he states that "the question of the emotions is not diluted in the subjective, but precisely the emotional repertoires collect and express how actors experience violence" (Bolívar, 2006: XLII), and the humiliation and rage are not only subjective questions, but they reveal the manner in which groups experience poverty, exploitation and marginalization.

Finally, this study found that in the process of young people transforming their subjectivities plays a great role the subjective time, which usually goes unnoticed. To support the return to civilian life it is important to develop actions that favor the subjective time already put in place, in order that each person elaborates their grief and achieve new social links, especially with civil society.

\section{References}

Alvarado, S. V., Martínez, J. E., \& Muñoz, D. A. (2009). Contextualización teórica al tema de la juventud: Una mirada desde las ciencias sociales a la juventud. Revista Latinoamericana de Ciencias Sociales, Niñez y Juventud, 7, 83-102.

Arfuch, L. (2002). El espacio biográfico. Dilemas de la subjetividad contemporánea. Buenos Aires: Fondo de Cultura Económica.

Arfuch, L. (2005). Identidades, sujetos y subjetividades. Buenos Aires: Prometeo.

Atehortúa, A. (2005). Militares. Otra visión, otros estudios. Bogotá: Universidad Pedagógica Nacional.

Bolívar, I. J. (2006). Discursos emocionales y experiencias de la política. Las FARC y las AUC en los procesos de negociación del conflicto. Bogotá: Ediciones Uniandes-COLCIENCIASCentro de investigación y educación popular (CINEP).

Brett, R., \& McCallin, M. (1998). Children: The Invisible Soldiers. Stockholm: RäddaBarnen.

Brett, R., \& Specht, I. (2005). Jóvenes soldados y combatientes. ¿Por qué van a luchar? Organización Internacional del Trabajo (OIT); Oficina Internacional del Trabajo (OIT); Comité Andino de Servicios y American Friends Service Committee.

Butler, J. (1997). Mecanismos psíquicos del poder. Teorías sobre la sujeción. Madrid: Ediciones Cátedra, Universidad de Valencia.

Castro, M. C. (2001). Del ideal y el goce. Lógicas de la subjetividad en la vía guerrillera y avatares en el paso a la vida civil. Bogotá: Universidad Nacional de Colombia. Facultad de Ciencias Humanas. Departamento de Psicología.

Castro, M. C., \& Díaz, C. L. (1997). Guerrilla, reinserción y lazo social. Bogotá: Almudena.

Coalición contra la vinculación de niños, niñas y jóvenes al conflicto armado en Colombia. (2009). El Delito invisible: Criterios para la investigación del delito de reclutamiento ilícito de niños y niñas en Colombia. Bogotá: Coalición contra la vinculación de niños, niñas y jóvenes al conflicto armado en Colombia; Comisión Colombiana de Juristas, Fondo de las Naciones Unidas para la Infancia(UNICEF); War Child Holanda en Colombia y Agencia de Cooperación Técnica Alemana al Desarrollo-GTZ-Proyecto Profis.

Coalition Stop the Use of Child Soldiers (2012). Louder than Words: An Agenda for Action to End State Use of Child Soldiers. Child Soldiers International.

De Coninck, F., \& Godard, F. (1998). El enfoque biográfico a prueba de interpretaciones: Formas temporales de causalidad. In Z. Lucero, L. Thierry, \& V. Pilar (Eds.), Los usos de la historia de vida en ciencias sociales (Vol. 2, pp. 250-292). Barcelona: Anthropos.

Estrada, A. M., \& Díazgranados, S. (2007). Kenneth Gergen: Construccionismo Social: Aportes para el debate y la práctica. Bogotá: Universidad de Los Andes.

Gergen, K. (1970). La psicología postmoderna y la retórica de la realidad. In I. Tomás (Ed.), EI 
conocimiento de la realidad social (pp. 157-185). Barcelona: Sendai.

Gergen, K. (1996). Realidades y relaciones: Aproximaciones a la construcción social. Barcelona: Paidós.

Goffman, E. (1961). Internados. Buenos Aires: Amorrortu Editores.

Human Rights Watch (2003). You'll Learn Not to Cry: Child Combatants in Colombia.

Ibañez, T. (1989). El conocimiento de la realidad social. Barcelona: Sendai.

Jiménez, C. (2006). Desobedecer para Convivir. Construcción de ciudadanía y campo psicosocial. Bogotá: Corporación Picacho con Futuro, Save the Children.

Jiménez, C., Muriel, A. M., \& Buitrago, H. A. (2011). Narrativas de construcción de la dignidad Módulos I y II. Bogotá: Defensoría del Pueblo.

Keairns, Y. (2004). Voces de jóvenes excombatientes. Bogotá: Comité Andino de Servicios (CAS), Quaker United Nations Office (QUNO).

Lara, L. M., \& Delgado, R. (2010). Trasegar de las subjetividades y las memorias de las y los jóvenes desmovilizados en el tránsito a la vida civil. Una mirada a los programas educativo y de apoyo psicosocial. Revista Universitas Humanística, 70, 29-56.

Londoño, L. M., \& Nieto, J. (2007). Mujeres no contadas. Medellín: La Carreta Editores.

Reguillo, R. (2000). Emergencia de culturas juveniles: Estrategias del desencanto. Bogotá: Norma.

Torres, A. (2000). Subjetividad y sujeto: Perspectivas para abordar lo social y lo educativo. Revista Colombiana de Educación, 50, 87-103.

Watch List (2004). On Children and Armed Conflict: Colombia's War on Children.

\section{Submit or recommend next manuscript to SCIRP and we will provide best service} for you:

Accepting pre-submission inquiries through Email, Facebook, LinkedIn, Twitter, etc. A wide selection of journals (inclusive of 9 subjects, more than 200 journals)

Providing 24-hour high-quality service

User-friendly online submission system

Fair and swift peer-review system

Efficient typesetting and proofreading procedure

Display of the result of downloads and visits, as well as the number of cited articles

Maximum dissemination of your research work

Submit your manuscript at: http://papersubmission.scirp.org/

Or contact ojps@scirp.org 